\title{
7
}

\section{Recruiting loyal stabilisers: On the banality of carceral colonialism in Xinjiang*}

Guldana Salimjan

W hile Uyghurs, Kazakhs, and other Turkic Muslim peoples are secretly transferred into prisons all over China (Bunin 2019; Kuo 2019; Jiang 2019), or reemerge as bare-minimum wage workers on the 'reeducation camp' factory floors (Byler 2019), China's settler institution, the Xinjiang Production and Construction Corps (兵团, Bingtuan), is facilitating new waves of Han influx from inner China (内地, neidi) to settle as farmers, civil servants, prison guards, police officers, and teachers. The totalitarian nature of such a massive human transfer is neutralised by the banal and procedural language of recruitment and employment-disguising the continued occupation and colonisation of Xinjiang.

State-sponsored Han migration into Xinjiang has been an important element in the militarisation and securitisation of the region since the founding of the People's Republic of China (Seymour 2000; Zhu and Blachford 2016). After October 1949, demobilised People's Liberation Army soldiers were recruited into production teams to establish mechanised state farms and ranches all over Xinjiang. In 1954, the Bingtuan was founded. Its development needs justified its grip on the region's vast grasslands and waterways, as well as the huge influx of ethnic Han migrant labourers. While early Bingtuan work was aimed at consolidating Communist Party power among the Kazakh population along the Sino-Soviet border (Moseley 1966; McMillen 1979), today's Bingtuan has expanded into a multi-billion-dollar urbanised corporation with its own jurisdiction and media that controls most agricultural industries in Xinjiang (Cliff 2009).

"This essay was originally published in the Made in China Journal (vol. 4, no. 3, 2019), doi.org/I 0.22459/MIC.04.03.2019.08. 
Since Chen Quanguo, the current CCP secretary of the Xinjiang Uyghur Autonomous Region, established his carceral regime in 2017, Bingtuan recruitment notices have frequently appeared on the websites of provincial governments, colleges, and universities in inner China. With the ever-expanding detention centres and camps (Doman et al. 2018), there has been a growing need to recruit assistant police staff in Xinjiang (Zenz and Leibold 2019). Unlike civil servant recruitment materials in other provinces, Bingtuan advertisements utilise propaganda discourse typically reserved for Xinjiang and Tibet, such as 'ethnic unity, national integrity and stability, anti-separatism, and illegal religious activities' to get politically obedient and manageable individuals to settle in Xinjiang (see Advertisements Nos 1, 2,3). The new recruits-usually college graduates and underemployed youths-are thus disengaged from the consequences of their settler-colonial practices. All parties involved in China's carceral colonialism in Xinjiang-Bingtuan, exam tutors, universities, state media, and new settlers-engage in an Orwellian 'newspeak' that comprises thoughtless teleological communist vocabularies of development, production, and employment. It is through such newspeak that the Bingtuan legitimises itself as a perpetual settler institution in Xinjiang and serves to cultivate colonial ideology and a sense of belonging for incoming generations of settlers.

\section{Choreographed loyalty}

As one of the major recruitment streams for civil servant positions (公务 员) for various Bingtuan regiments, these advertisements are often seen on the 'career' webpages of Chinese universities (see Advertisements Nos 1,2). Civil service positions are popular among college graduates in China as they offer stable income and better welfare than jobs in the private sector or self-employment. These Bingtuan recruitments are particularly systematic, targeting recruits from specific provinces or cities, aiming to ensure long-term settlement by providing attractive social benefits packages.

Unlike civil servant recruitment in other provinces, these Bingtuan recruitments put extra emphasis on the evaluation of the applicants' 'practical performance in safeguarding national unity, ethnic unity, and social stability' (其在维护祖国统一、维护民族团结、维护社会稳定 中的现实表现) (see Advertisement No. 3). According to a recruitment advertisement posted in December 2018, the Bingtuan was calling for 
237 civil servant applicants from the provinces of inner China (excluding Tibet and Qinghai) (see Advertisement No. 4). The recruitment targeted college graduates under 30 years of age for positions at various Bingtuan regiments in southern Xinjiang, including the 1st Division in Aral City in Aksu, the 2nd Division in Tiemenguan City in Korla, and the 3rd Division in Tumshuk City in Kashgar. The applicants would undergo interviews and background checks in inner China in cities such as Shenyang, Zhengzhou, Changsha, and Lanzhou. The recruiting personnel would examine the applicants' eligibility, including their 'political quality' (政治素质), 'thought quality' (思想品质), 'adaptability' (适 应能力), 'psychological quality' (心理素质), 'volunteering spirit' (奉献精 神), and 'discipline and law-abiding quality' (遵纪守法). The minimum service period was five years. Successful applicants would be reimbursed for the cost of their round trip to Xinjiang.

Among the following recruitments from Gansu, Jilin, Inner Mongolia, Anhui, Hebei, and Shanxi, applicants for the positions in Hotan were not even required to sit a written exam (see Advertisement Nos 5, 6). Successful applicants were promised a high salary, housing, official rank, and social security benefits. The state even offered to reimburse their graduate school tuition at the rate of 8,000 yuan per year (see Advertisement Nos 5-8). Eligibility once again depended on political performance. Applicants had to be college graduates with membership or preliminary membership of the CCP (see Advertisement Nos 5-9).

To prepare for these political performance interviews, applicants can sign up for online training courses streamed on mobile phones by scanning a QR code and logging into an official WeChat site. The courses teach applicants to mimic the tones and gestures of Communist Party cadres during an interview. For instance, in one of these videos, a tutor teaches the applicants to perform an enthusiastic endorsement of ' $\mathrm{Xi}$ Jinping Thought' like an actor: 'The key is to speak nonsense in a serious manner [一本正经的胡说八道] [see Advertisement No. 12]. You need to act like someone who belongs to the system. It is all about acting skills [拼演技].' Speaking to the broader audience from inner China, this tutor is grooming politically apathetic college graduates to participate in everyday political performances of loyalty in Xinjiang, where Communist Party 'nonsense' is a serious matter. 
Table 7.I Examples of Bingtuan civil servant recruitment notices

\begin{tabular}{|c|c|c|c|c|}
\hline $\begin{array}{l}\text { Date } \\
\text { published }\end{array}$ & $\begin{array}{l}\text { No. of } \\
\text { people }\end{array}$ & $\begin{array}{l}\text { Recruited } \\
\text { from }\end{array}$ & Recruited to & $\begin{array}{l}\text { Advertisement } \\
\text { no. }\end{array}$ \\
\hline 3 Jul 2017 & 113 & $\begin{array}{l}\text { Sichuan } \\
\text { Province }\end{array}$ & $\begin{array}{l}\text { Various Bingtuan divisions: } \\
\text { 6th, 8th, Ürümqi (i.e. Changji, } \\
\text { Shihezi) }\end{array}$ & 17 \\
\hline 8 Dec 2017 & 80 & $\begin{array}{l}\text { Provinces of } \\
\text { inner China }\end{array}$ & $\begin{array}{l}\text { Various Bingtuan divisions: } \\
\text { Ist, 2nd, 3rd, I 4th (i.e. Aksu, } \\
\text { Bayingol,Tumshuk, Hotan) }\end{array}$ & 18 \\
\hline I| Aug 2018 & 1,348 & $\begin{array}{l}\text { Provinces of } \\
\text { inner China }\end{array}$ & $\begin{array}{l}\text { Various Bingtuan prison } \\
\text { systems }\end{array}$ & 19 \\
\hline $19 \operatorname{Mar} 2019$ & 524 & $\begin{array}{l}\text { All police school } \\
\text { graduates in } \\
\text { China }\end{array}$ & $\begin{array}{l}\text { Various Bingtuan divisions: } \\
\text { Ist, 2nd, 3rd, I 4th (i.e. Aksu, } \\
\text { Bayingol,Tumshuk, Hotan) }\end{array}$ & 20 \\
\hline 15 Apr 2019 & 49 & $\begin{array}{l}\text { Provinces of } \\
\text { inner China }\end{array}$ & $\begin{array}{l}\text { Bingtuan 2nd division } \\
\text { (i.e. Bayingol) }\end{array}$ & 21 \\
\hline 10 May 2019 & 330 & Hebei Province & $\begin{array}{l}\text { Bingtuan 2nd division } \\
\text { (i.e. Bayingol) }\end{array}$ & 22 \\
\hline
\end{tabular}

Online tutorials also disseminate official settler-colonial ideology about Xinjiang in relation to securitisation and ethnic integration. In another video, a tutor shares with his viewers a real question that was asked during a Bingtuan job interview (see Advertisement No. 13):

Xi Jinping said: 'Make Bingtuan the stabiliser of the frontier, the melting pot of different ethnic groups, and the exemplar of advanced productivity and modern culture.' Please discuss your thoughts on this quote considering the practical situation of Bingtuan and explain the relationship between the three aspects.

Fully costumed like a China Central Television anchor, the tutor gives a model answer in perfect Mandarin pronunciation:

Stabiliser, melting pot, and exemplar region are strong indications of our party's work in land reclamation and border reinforcement, [and] also an excellent summary of our Bingtuan mission. To be the frontier stabiliser is the basic requirement for Bingtuan's land reclamation and border reinforcement. Well known for its large 
scale, numbers, and strong ability, combining military police in battle in quelling separatist and unrest activities, Bingtuan is an important force to maintain border stability and security. Unifying different ethnic groups in a melting pot is another role Bingtuan is playing. For a long time, Bingtuan has implemented the party's ethnic policy, and stressed the unity, development, and prosperity of all ethnic groups, promoting harmonious living and peaceful coexistence ... In my future work, I will also practise these three points. I will lead by example by staying close to the border masses, close the gap between us, and integrate with the masses.

\section{Loyal education and police spirit}

As can be seen in Table 7.2, prison guard positions constitute another rising employment stream into southern Xinjiang, where many 'reeducation camps' are located. Among all civil servants recruited by the Bingtuan in 2018, prison personnel made up more than one-third of the total prospective employees (see Advertisement No. 14). For these positions, the 'political quality' (政治素质) criterion was more concrete and even family members were under scrutiny. People with criminal or correctional records were not allowed to apply. If the applicants had a relative within three generations who had been sentenced to death, endangered state security, incited ethnic separatism, conducted illegal religious activity, or practised Falun Gong, they were not eligible.

A Bingtuan recruitment drive for 500 prison guards in 2019 did not require a written exam, only a face-to-face interview (see Advertisement No. 15). Such an exemption is rare and indicates to some degree the state's growing need for security forces in Xinjiang. In another video, a tutor introduces the eligibility requirements for the positions in the regiment's prisons, as well as which cities they are in (see Advertisement No. 16). At minute 19:30, he casually says:

Many of you might have looked up the specific locations of these prisons on Baidu Maps but couldn't find them. Prisons are supposed to be secretive. Of course, we can't mark the location of the prisons otherwise it would look like there are prisons everywhere; it's not good, right? 
It is worth mentioning that once selected for the position, applicants for prison guards must receive systematic political indoctrination. At the end of 2018, the Bingtuan prison system initiated a series of 'loyalty education programs' (忠诚教育) to reinforce 'loyal police spirit' (忠诚 警魂), which included the compulsory study of 21 essays on Xi Jinping Thought, the Communist Party Constitution, Xinjiang history, and the history of Bingtuan land reclamation (Ministry of Justice 2018). Police and prison guards must study for at least one hour every day and always carry with them the Bingtuan Prison Police 'Loyalty Education' Study Manual (兵团监狱民警“忠诚教育'应知应会手册). Employees must establish 'four kinds of consciousness' (四个意识) 一 that is, political consciousness, overall situation consciousness, core consciousness, and unification consciousness-regularly write reflections, participate in patriotic red song choruses, watch patriotic films, participate in 'Inheriting Red Genes, Practising Bingtuan Spirit' (传承红色基因.践行兵团精神) speaking contests and seminars, and so on. There is a monthly examination and those who fail are criticised. Employees must also denounce 'two-faced people' (两面人) among their ranks and participate in the 'Becoming Families' campaign (访民情、惠民生、聚民心), which is aimed at spying on the ethnic minorities in the Bingtuan regiments in southern Xinjiang.

Table 7.2 A selection of Bingtuan police recruitment notices since 2017

\begin{tabular}{lllll}
\hline Date & $\begin{array}{l}\text { No. of } \\
\text { people }\end{array}$ & $\begin{array}{l}\text { Recruited } \\
\text { from }\end{array}$ & Destination & $\begin{array}{l}\text { Advertisement } \\
\text { no. }\end{array}$ \\
\hline 9 Nov 2018 & III & $\begin{array}{l}\text { Anhui, Henan, } \\
\text { Shanxi }\end{array}$ & $\begin{array}{l}\text { Regiments of the 14th } \\
\text { Division, Kunyu City } \\
\text { (Qurumqax in Hotan) }\end{array}$ & 3 \\
\hline 9 Nov 2018 & 61 & Hubei, Gansu & Ist Division, Aral City, Aksu & 10 \\
\hline 9 Nov 2018 & 48 & Hebei, Shanxi & $\begin{array}{l}\text { 2nd Division, Tiemenguan } \\
\text { City, Korla }\end{array}$ & 9 \\
\hline 18 Dec 2018 & 237 & Provinces of & $\begin{array}{l}\text { Ist, 2nd, 3rd, I4th Divisions, } \\
\text { inner China } \\
\text { Aral,Tiemenguan, Tumshuk, } \\
\text { Qurumqax in Hotan }\end{array}$ & 4 \\
\hline 26 Mar 2019 & 620 & $\begin{array}{l}\text { Provinces of } \\
\text { inner China }\end{array}$ & $\begin{array}{l}\text { Various Bingtuan regiments } \\
\text { and police stations }\end{array}$ & II \\
\hline
\end{tabular}




\section{(Un)transferrable belonging: Farmers and workers}

Another stream that absorbs a huge number of Han labourers from inner China is the 'employment transfer' (转移就业) program, which targets less-educated farmers and workers under 40 years of age. Households of Han settlers are particularly welcome. Unlike the above-mentioned civil servant and prison guard recruitment streams that focus on political conformity and reliability, this stream's recruitment advertisements clearly explain levels of agricultural production, land area, working seasons, and annual income for the farmers, and offer full packages of social welfare that are unfathomable in the hometowns of the potential applicants.

According to a 2018 recruitment campaign targeting farmers from Henan Province, holders of agricultural hukou (household registration) would be given non-agricultural hukou once they were settled in Xinjiang and their trip fares would be reimbursed (see Advertisement No. 23). New employees are provided rent-free accommodation for four years in apartments equipped with electricity and heating. Couples will both receive registered positions to grow cotton on $35 \mathrm{mu}$ ( 2.3 hectares) of land each and are given land at the end of their first year in Xinjiang. For China's vast population of economically precarious farmers and migrant workers, social and medical insurance are among the most attractive benefits for settling in Xinjiang. The new employees and all their family members are fully covered by health, unemployment, and retirement insurance.

Neighbouring provincial governments such as Gansu and Ningxia are collaborating with the Bingtuan to transfer their impoverished farmers to various regiments in Xinjiang. After a 'farewell ceremony' (欢送大会), impoverished people are finally out of sight, out of mind for the officials of the sending governments. A single county in Ningxia had a quota of 900 people to be transferred to Xinjiang in 2017 (see Advertisement No. 24). In a video recruitment advertisement for the Bingtuan 1st Division in Aral City, Aksu, where more than 99 per cent of the population is Han, the narrator stresses the local population is scarce and the need for labour input is urgent and necessary (see Advertisement No. 25). She then sets out the recruitment plan for each regiment as part of the Thirteenth Five-Year Plan in the region. To take a few examples from a long list: the 14th Regiment is planning to recruit 9,000 people; the 224th Regiment is planning to recruit 5,600 people; the 14th Division is planning to recruit 650 households (Bingtuan recruitments favour households over individuals, as whole families are more likely to settle down), and so on. 
Again, the benefits for settlers are astounding. Each settler will receive $20 m u$ ( 1.3 hectares) of land for each type of crop cultivated by the regiment. The settlement's housing is equipped with living supplies and rent is subsidised for the first three years. Each settler couple can earn 1,500 yuan in housing subsidies per month, including social security and hukou transfer procedures. Some regiments even provide apartments to households with six or more people. Their rent is subsidised as well and can be used towards a mortgage with the aim of eventually owning the property. Settlers' children can attend local schools without having to pay for tuition for 15 years and can enjoy added points on their college entrance examination scores (高考加分) - an affirmative action policy that has historically been directed towards Uyghurs and other ethnic minorities in Xinjiang. However, despite all these benefits, many households are not interested in moving and, according to a report from Dingxi, Gansu (Li 2019), some poor households have been threatened and coerced into relocating-with those refusing cut off from the social guarantees for impoverished families. The local government ensured relocated households did not return to Gansu by revoking their hukou and confiscating their land and houses. Villagers also revealed that, in some cases, the promised benefits did not materialise.

Despite all this, Sina.com (2018) painted a rosy picture of one farmer's employment transfer from Dingxi in Gansu to Xinjiang, titled 'Make a Home Across 3,000 Kilometres'-an experience almost too good to be true and starkly different from the stories of manipulation and coercion reported by independent sources (Li 2019).

The protagonist of Sina.com's report is Cao Yongping. His hometown, Bailu village, is the poorest in the whole province. Environmental deterioration in recent years has pushed many of his fellow villagers to find work in the cities, and Cao himself has made several attempts to leave the countryside and get out of poverty. A few years ago, he took out a 100,000-yuan loan and purchased a long-haul truck to transport vegetables between Lanzhou and Chengdu. In 2016, he broke his ribs in a traffic accident and was unable to continue this work. He has since been in debt and has been unable to repay his loan.

In February 2017, various divisions of the Bingtuan began to recruit workers from Dingxi. The slogan for the recruitment campaign was 'Relocation employment in a systematic, organised, and scaled manner' (有计 划、有组织、有规模地进行转移就业). Cao learned that if he chose to relocate to Xinjiang, he could immediately move into an apartment of 
80 square metres with $70 \mathrm{mu}$ (4.7 hectares) of allotted land, plus 15 years of free education for his children. Many farmers like Cao were recruited by the Bingtuan to cultivate land and settle as long-term farm employees. Cao had to learn from his father how to do agricultural work. After much preparation, Cao took his wife and children to Xinjiang first, leaving his elderly father behind to take care of the rest of the relocation work.

In 2018, Cao's family arrived in Tumshuk County on the outskirts of Kashgar, 3,100 kilometres from his home village. They became the first household of the Bingtuan 'employment transfer' program. Unlike previous waves of migrant workers to Xinjiang, workers enrolled in this program are required to settle down. Cao's family was to settle in the 50th Regiment in Tumshuk. Fellow villagers from Dingxi picked them up and registered them at the regiment's office. Cao was given the option of living in an apartment or in a one-storey house close to his allotted land. Since he planned to bring his parents as well, he chose the house, which had three bedrooms, a living room, and a courtyard.

In their new residence, all the necessities of life and furniture were already installed. The regiment leader told Cao that their regiment's renovation fee was the highest among all regiments, as water, electricity, the gas stove and hot water, and even food and cleaning supplies were all provided. Cao's family was assigned to one of dozens of traditional Chinese Hui style houses, with an 85-square-metre courtyard, where they could live rent-free for six years. Cao thought he would have to work for more than 10 years to achieve these kinds of living conditions in Dingxi. Although he worried about safety issues in Xinjiang, his fellow Dingxi compatriots told him this place was now safer than anywhere in China. Two weeks later, Cao's parents arrived after selling their pigs back home. Cao's children have registered in local schools. A new life has begun for them.

\section{Epilogue}

Like a drop of water disappearing into a vast sea, Cao and his family faded into the state machine of human transfers in China. At the first dinner after settling down at the regiment, Cao commented that the potatoes in Xinjiang are not as delicious as in Dingxi. Sina.com's journalist allowed this humanistic moment of recalcitrance in Cao's story. On a broader scale, state-sponsored Han settlement in Xinjiang is normalised by this kind of triumphant narrative of poverty-alleviation campaigns, burying the 
inconvenient truth that sees the dilution, incarceration, and replacement of native populations in Xinjiang. Cao would not be burdened by the thought of benefiting from stolen land. He has settled permanently in Xinjiang, just as countless Uyghurs and Kazakhs have been indefinitely imprisoned behind the barbed wire just a few miles away, in reeducation camps staffed by other hopeful new migrants from inner China.

The continued challenge facing the Bingtuan lies in cultivating a sense of loyalty and belonging among the newest waves of Han immigrants from inner China, who are different from both the older generations of Han settlers who arrived after the 1950s and the economically motivated migrant subalterns who arrived in the 1990s, such as those described by Tom Cliff (2016) in his recent ethnography of Bingtuan Han settlers, Oil and Water. These new waves of incoming Han add biopolitical fuel to Chen Quanguo's carceral regime, which in return provides solid ground for the political and economic legitimacy of the Bingtuan. Through the CCP's banal, technocratic discourses of employment and political loyalty, the Bingtuan fulfils the state's mission of securitising Xinjiang. Yet, at the same time, it also securitises the potentially unstable situations created by the surplus of underemployed Han youth in the countryside and cities of inner China-a problem continuously exacerbated by ongoing land dispossession and wealth disparity. 
This text is taken from Xinjiang Year Zero, edited by Darren Byler, Ivan Franceschini and Nicholas Loubere, published 2022, The Australian National University, Canberra, Australia. 